\title{
Dissemination of Citrus Greening in Puerto Rico',
}

\author{
Margarita R. Marroquin-Guzman ${ }^{3}$ and Consuelo Estevez \\ de Jensen ${ }^{4}$
}

J. Agric. Univ. P.R. 97(3-4):119-134 (2013)

\begin{abstract}
Citrus Greening (CG) caused by a phloem restricted bacteria, Candidatus Liberibacter asiaticus ( $\mathrm{Ca}$. L. asiaticus), is one of the most devastating diseases of citrus worldwide. The disease dramatically affects the production of citrus trees. Following the detection of CG in Puerto Rico, a survey was conducted from February 2011 to March 2012 to determine the dissemination of the pathogen. Twenty orchards and seven nurseries located in the central mountain region, southern coast, northern and northwestern region of the island were sampled. Symptomatic and asymptomatic plants were collected and processed at the plant disease clinic of the University of Puerto Rico (UPR) Agricultural Experiment Station in Juana Diaz, Puerto Rico. A total of 345 samples were analyzed by Polymerase Chain Reaction using primers Ol 1 and Ol2. Citrus Greening was detected in only $7.0 \%$ of the symptomatic samples collected in eight orchards covering an area of 235 hectares in the municipalities of Adjuntas, Añasco, Cabo Rojo, Coamo, Dorado, Juana Díaz, Las Marías and Santa Isabel. In 42 samples negative for $\mathrm{Ca}$. L. asiaticus, two additional diseases were tested by serological methods: Citrus Tristeza Virus (CTV) and Citrus Variegated Chlorosis (CVC). Both diseases were detected: CVC in a sample from Ciales, CTV in 41 samples from various municipalities. Regular screening of $\mathrm{Ca}$. L. asiaticus in orchards and nurseries, vector control strategies and removal of CG infected trees should be implemented to protect the citrus industry on the island.
\end{abstract}

Keywords: Candidatus Liberibacter asiaticus, polymerase chain reaction (PCR), Citrus Greening

\section{RESUMEN}

\section{Diseminación del enverdecimiento de los cítricos en Puerto Rico}

El enverdecimiento de los cítricos (EC), causado por la bacteria limitada al floema Candidatus Liberibacter asiaticus ( $\mathrm{Ca}$. L. asiaticus), es una de las enfermedades más devastadoras para la citricultura en el mundo. La enfermedad afecta dramáticamente la producción de los árboles de cítricos.

${ }^{1}$ Submitted to the Editorial Board 29 September 2013.

${ }^{2}$ Funding for this project was provided by TSTAR-135 award \# 2010-34135-21014.

${ }^{3}$ Former graduate student, Department of Crops and Agroenvironmental Sciences, University of Puerto Rico, Mayagüez, Puerto Rico. E-mail: mmarroquin-guzman@huskers.unl.edu

${ }^{4}$ Associate Professor, Department of Crops and Agroenvironmental Sciences, University of Puerto Rico, Agricultural Experiment Station, Juana Díaz, Puerto Rico. 
Después de la detección del EC en Puerto Rico, se realizó un monitoreo para la determinación de la diseminación del patógeno desde Febrero de 2011 hasta Marzo de 2012. Se tomaron muestras sintomáticas y asintomáticas en siete viveros y veinte huertos en la región central montañosa, costa sur, norte y noroeste de la isla. Las muestras se procesaron en la clínica de diagnóstico de la Universidad de Puerto Rico, Estación Experimental Agrícola de Juana Díaz. En un total de $\mathbf{3 4 5}$ muestras se realizó la reacción en cadena de la polimerasa con los iniciadores Ol1 y Ol2. EI EC se detectó en solamente $7.0 \%$ de las muestras provenientes de ocho huertos con un área de $\mathbf{2 3 5}$ hectáreas en las localidades de Adjuntas, Añasco, Cabo Rojo, Coamo, Dorado, Juana Díaz, Las Marías y Santa Isabel. En 42 muestras negativas para $\mathrm{Ca}$. L. asiaticus se realizaron pruebas serológicas para identificar: el Virus de la Tristeza (VTC) y la Clorosis Variegada de los Cítricos (CVC). Las dos enfermedades se detectaron: VTC en una muestra de ciales, y CVC en 41 muestras de diferentes localidades. La detección periódica de la presencia de la bacteria en los huertos comerciales, el control del vector y la eliminación de árboles infectados con EC deberá implementarse para proteger la industria citrícola en la Isla.

Palabras clave: Candidatus Liberibacter asiaticus, reacción en cadena de la polimerasa (PCR), serología

\section{INTRODUCTION}

Citrus production ranks as the second in fruit crops in Puerto Rico with 7,500 acres planted in 2010-2011, and net production valued at $\$ 10$ million (Anonymous, 2011). Citrus spp. are widely planted in Puerto Rico with over 2,800 farms in the mountainous region of the island. Citrus Greening (CG) is considered the most destructive disease of citrus in the world (Bové, 2006; Brlansky and Rogers, 2007; Callaway, 2008; Gottwald et al., 2007; Stokstad, 2006). The disease is caused by an endogenous, sieve tubes-restricted bacteria, which is transmitted by citrus psyllid vectors: Diaphorina citri Kuwayama in Asia and America, and Trioza erytreae Del Guercio in Africa (Bové, 2006). The disease has been associated with three different species: Candidatus Liberibacter asiaticus in Asia, Ca. L. africanus in Africa (Jagoueix et al., 1994), and Ca. L. americanus in Brazil (Teixeira, 2005).

Infected trees develop blotchy-mottled or completely yellow chlorotic leaves, resembling mineral deficiencies (zinc, iron, magnesium, calcium and copper), fruits are small, lopsided and bitter-tasting with small and aborted seeds. As the disease progresses, tree growth and fruit yield are significantly reduced, making the orchard economically not viable (Folimonova and Achor, 2010).

Approximately 100 million infected citrus trees have been destroyed by the disease throughout Asia, with an additional one million trees eliminated in Brazil since the first report of the disease in 2004 (Gottwald et al., 2007). In the United States, CG was first detected in August 2005 in South Florida, seven years after the introduction of 
the psyllid vector, $D$. citri (Sutton et al., 2005). Since that time, CG has spread to all Florida's citrus-growing counties, and in the states of Louisiana, South Carolina, California, Texas, Arizona and Georgia (USDA, 2011). At present, there is no adequate control of the disease, increasing its incidence and severity where it occurs. The first line of defense for CG has always been quarantines to ensure that the bacteria is not introduced and established (Gottwald, 2010).

In Puerto Rico, CG was detected and reported in 2009 in an orchard at the UPR Experiment Station of Isabela (Estevez de Jensen et al., 2009). Subsequently, $\mathrm{Ca}$. L. asiaticus was identified in commercial orchards in the locations of Castañer (Adjuntas), Yahuecas (Adjuntas), and in a three-year old Tahiti lime orchard in the UPR Agricultural Experiment Station of Juana Diaz. Symptoms developed from mottled areas and yellowed shoots, to stem and limb dieback within five months in 81 out of 352 trees (Estevez Jensen et al., 2010). The vector D. citri was reported earlier in the island on the coast of Isabela and the mountains of Adjuntas in June 2001 (Halbert and Nuñez, 2004).

The accurate identification of CG in Puerto Rico at the field level is hindered by the similarities between nutritional deficiencies and other diseases affecting the vascular system and therefore causing similar symptoms, such as Tristeza Virus (CTV) (Yokomi et al., 1996) and Variegated Chlorosis (CVC) (Zapata et al., 2011). The lack of a plant health verification protocol in nurseries in Puerto Rico have aggravated CG. The identification of CG in the host relies on molecular diagnostic techniques such as the polymerase chain reaction (PCR) and the real time PCR. The objective of this study was to survey the Puerto Rican citrus growing regions for detection of $\mathrm{CG}$ using the polymerase chain reaction technique to determine the disease spread.

\section{MATERIALS AND METHODS}

Collection of samples. From February 2011 to March 2012, a CG survey was conducted in the citrus producing areas of Puerto Rico. Sampling dates, geographical coordinates and citrus species sampled during the survey are shown on Table 1 . In total, twenty commercial orchards and seven nurseries were sampled across the island (Figure 1).

Leaf samples were collected from the middle branches of symptomatic trees showing blotchy-mottled leaves or thickening and cleared midribs with yellow shoots (Figure 2). For each site (orchard or nursery) five randomly selected symptomatic trees were sampled.

Asymptomatic leaf samples were also collected from the middle branches of healthy plants. Samples were placed in a plastic bag 
TABLE 1. - Information associated with Citrus spp. samples collected in Puerto Rico for the detection of Candidatus Liberibacter asiaticus, causal agent of Citrus Greening.

\begin{tabular}{|c|c|c|c|c|}
\hline Sampling date & Municipality & Geographical coordinates & Host & $\begin{array}{l}\text { Number of } \\
\text { samples }\end{array}$ \\
\hline \multirow[t]{3}{*}{ Apr 5, 2011} & Adjuntas (nursery and orchard) & N18 ${ }^{\circ}$ 10.524' W66우 47.911' & $\begin{array}{l}\text { C. sinensis } \\
\text { C. reticulata }\end{array}$ & $\begin{array}{l}30 \\
10\end{array}$ \\
\hline & & & C. latifolia & 7 \\
\hline & & & C. reticulata $x$ C. paradisi & 7 \\
\hline $\operatorname{Mar} 27,2012$ & Añasco (orchard) & $\mathrm{N} 18^{\circ} 18.145^{\prime} \mathrm{W} 67^{\circ} 03.680^{\prime}$ & C. sinensis & 10 \\
\hline Jan 23, 2012 & Arecibo (nursery and orchard) & $\mathrm{N} 18^{\circ} 24.453^{\prime} \mathrm{W} 66^{\circ} 35.612^{\prime}$ & $\begin{array}{l}\text { C. reticulata } \\
\text { C. sinensis }\end{array}$ & $\begin{array}{l}10 \\
10\end{array}$ \\
\hline \multirow[t]{6}{*}{ July 12,2011} & Cabo Rojo (nursery and orchard) & $\mathrm{N} 18^{\circ} 04.170^{\prime} \mathrm{W} 67^{\circ} 08.896^{\prime}$ & $\begin{array}{l}\text { C. nobilis } \\
\text { C. sinensis }\end{array}$ & $\begin{array}{r}15 \\
2\end{array}$ \\
\hline & & & C. reticulata & 11 \\
\hline & & & C. latifolia & 5 \\
\hline & & & C. reticulata $x$ C. paradisi & 7 \\
\hline & & & C. paradisi & 1 \\
\hline & & & C. limon & 5 \\
\hline Nov 6, 2011 & Cayey (orchard) & $\mathrm{N} 18^{\circ} 14.002^{\prime} \mathrm{W} 66^{\circ} 06.928^{\prime}$ & C. reticulata & 2 \\
\hline Feb 26, 2011 & Ciales (orchard) & $\mathrm{N} 18^{\circ} 17.603^{\prime} \mathrm{W} 66^{\circ} 32.152^{\prime}$ & $\begin{array}{l}\text { C. sinensis } \\
\text { C. reticulata }\end{array}$ & $\begin{array}{l}7 \\
6\end{array}$ \\
\hline Apr 26, 2011 & Coamo (orchard) & $\mathrm{N} 18^{\circ} 01.783^{\prime} \mathrm{W} 66^{\circ} 21.498^{\prime}$ & C. aurantifolia & 5 \\
\hline \multirow[t]{4}{*}{ May 13,2011} & Corozal (nursery and orchard) & $\mathrm{N} 18^{\circ} 20.356^{\prime} \mathrm{W} 66^{\circ} 19.630^{\prime}$ & $\begin{array}{l}\text { C. reticulata } \\
\text { C. latifolia }\end{array}$ & $\begin{array}{l}4 \\
1\end{array}$ \\
\hline & & & C. paradisi & 2 \\
\hline & & & C. sinensis & 12 \\
\hline & & & C. reticulata $\times$ C. paradisi & 2 \\
\hline
\end{tabular}


TABLE 1.-(Continued) Information associated with Citrus spp. samples collected in Puerto Rico for the detection of Candidatus Liberibacter asiaticus, causal agent of Citrus Greening.

\begin{tabular}{|c|c|c|c|c|}
\hline Sampling date & Municipality & Geographical coordinates & Host & $\begin{array}{l}\text { Number of } \\
\text { samples }\end{array}$ \\
\hline \multirow[t]{2}{*}{ Dec 7, 2011} & \multirow[t]{2}{*}{ Dorado (orchard) } & \multirow[t]{2}{*}{$\mathrm{N} 18^{\circ} 02.006^{\prime} \mathrm{W} 66^{\circ} 31.856^{\prime}$} & $\begin{array}{l}\text { C. reticulata } \\
\text { C. sinensis }\end{array}$ & $\begin{array}{r}10 \\
4\end{array}$ \\
\hline & & & C. aurantifolia & 13 \\
\hline Apr 8, 2011 & Guánica (orchard) & $\mathrm{N} 18^{\circ} 26.318^{\prime} \mathrm{W} 66^{\circ} 17.535^{\prime}$ & $\begin{array}{l}\text { C. sinensis } \\
\text { C. latifolia }\end{array}$ & $\begin{array}{r}5 \\
10\end{array}$ \\
\hline \multirow[t]{2}{*}{ Feb 10, 2011} & \multirow[t]{2}{*}{ Isabela (nursery) } & \multirow[t]{2}{*}{$\mathrm{N} 18^{\circ} 27.938^{\prime} \mathrm{W} 67^{\circ} 03.146^{\prime}$} & $\begin{array}{l}\text { C. sinensis } \\
\text { C. reticulata } x \text { C. paradisi }\end{array}$ & $\begin{array}{l}5 \\
1\end{array}$ \\
\hline & & & C. latifolia & 4 \\
\hline $\operatorname{Mar} 29,2011$ & Juana Díaz (orchard) & $\mathrm{N} 18^{\circ} 02.006^{\prime} \mathrm{W} 66^{\circ} 31.856^{\prime}$ & C. latifolia & 5 \\
\hline \multirow[t]{2}{*}{ Oct 27,2011} & \multirow[t]{2}{*}{ Lares (orchard) } & \multirow[t]{2}{*}{ 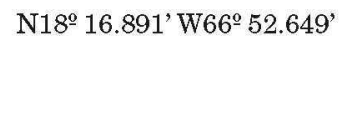 } & $\begin{array}{l}\text { C. sinensis } \\
\text { C. reticulata }\end{array}$ & $\begin{array}{l}1 \\
1\end{array}$ \\
\hline & & & C. paradisi & 1 \\
\hline \multirow[t]{4}{*}{ June 9, 2011} & \multirow[t]{4}{*}{ Las Marías (nursery and orchard) } & \multirow[t]{4}{*}{ N18 $13.040^{\prime}$ W66 $56.475^{\prime}$} & $\begin{array}{l}\text { C. nobilis } \\
\text { C. sinensis }\end{array}$ & $\begin{array}{l}5 \\
5\end{array}$ \\
\hline & & & C. reticulata & 14 \\
\hline & & & C. latifolia & 10 \\
\hline & & & C. paradisi & 1 \\
\hline Nov 10,2011 & Morovis (orchard) & $\mathrm{N} 18^{\circ} 33.990^{\prime} \mathrm{W} 60^{\circ} 41.008^{\prime}$ & C. paradisi & 2 \\
\hline Oct 3,2011 & Sabana Grande (orchard) & N18º 05.033’ W66 57.417' & $\begin{array}{l}\text { C. sinensis } \\
\text { C. reticulata }\end{array}$ & $\begin{array}{l}7 \\
4\end{array}$ \\
\hline
\end{tabular}


TABLE 1.-(Continued) Information associated with Citrus spp. samples collected in Puerto Rico for the detection of Candidatus Liberibacter asiaticus, causal agent of Citrus Greening.

\begin{tabular}{|c|c|c|c|c|}
\hline Sampling date & Municipality & Geographical coordinates & Host & $\begin{array}{l}\text { Number of } \\
\text { samples }\end{array}$ \\
\hline Nov 19, 2011 & San Sebastián (orchard) & N18은 $20.567^{\prime}$ W66 $59.683^{\prime}$ & C. sinensis & 10 \\
\hline May 24, 2011 & Santa Isabel (orchard) & $\mathrm{N} 17^{\circ} 99.462^{\prime} \mathrm{W} 66^{\circ} 36.905^{\prime}$ & C. sinensis & 10 \\
\hline \multirow[t]{2}{*}{ Sep 12, 2011} & Utuado (orchard) & N18은 $18.512^{\prime}$ W66 $35.103^{\prime}$ & $\begin{array}{l}\text { C. reticulata } \\
\text { C. nobilis }\end{array}$ & $\begin{array}{l}8 \\
1\end{array}$ \\
\hline & & & C. sinensis & 11 \\
\hline $\operatorname{Jan} 25,2012$ & Villalba (orchard) & N18 ${ }^{\circ} 16.401^{\prime}$ W66 $50.507^{\prime}$ & C. reticulata & 5 \\
\hline \multirow[t]{2}{*}{ May 20, 2011} & Yauco (orchard) & $\mathrm{N} 18^{\circ} 08.981^{\prime} \mathrm{W} 66^{\circ} 49.036^{\prime}$ & C. sinensis & 11 \\
\hline & & TOTAL & & 345 \\
\hline
\end{tabular}




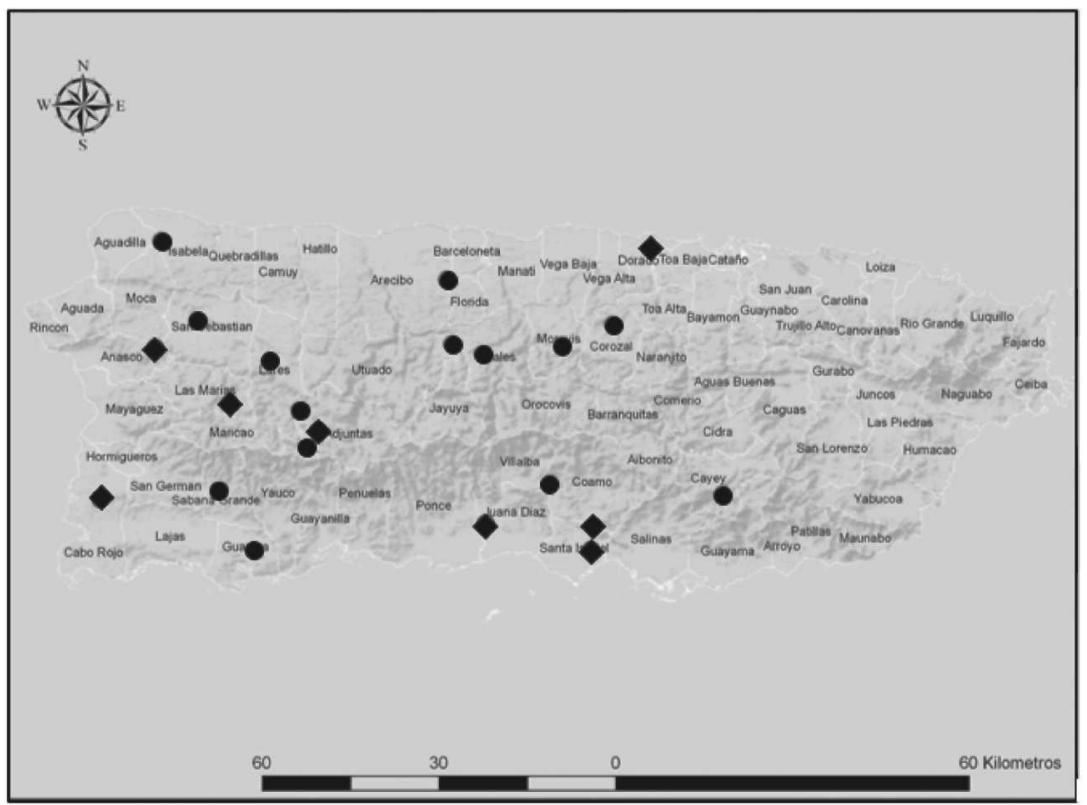

FIGURe 1. Areas sampled for Citrus Greening in Puerto Rico, February 2011 to March 2012. Dots correspond to locations where CG was not detected and the squares represent the locations where $C a$. L. asiaticus was identified.

individually identified, and transported in a cooler to the plant disease clinic located at the UPR Agricultural Experiment Station in Juana Díaz. Young shoots were also collected from the middle of trees in orchards at Adjuntas, Añasco, Coamo, Juana Díaz and Dorado, in order to count number of adults of $D$. citri using a stereoscope (Olympus).

DNA extraction, PCR and sequencing. Total DNA was extracted from $100 \mathrm{mg}$ of fresh leaf midribs using the DNeasy Plant Mini Kit (Quiagen, Valencia, CA) ${ }^{5}$ according to the manufacturer's instructions. Standard PCR was performed using Master Mix Go Green Tag (Promega, Madison, WI) and primers OI1 (5'CGCCGTATGCAATACGAGCGGCA3') and OI2 (5'GCCTCGCGACTTCGCAACCCAT 3') (Gottwald et al., 1989; Jagoueix et al., 1996; Li et al., 2007). Positive controls were Citrus latifolia infected trees located at the UPR Agricultural Experi-

${ }^{5}$ Company or trade names in this publication are used only to provide specific information. Mention of a company or trade name does not constitute a warranty of equipment or materials by the Agricultural Experiment Station of the University of Puerto Rico, nor is this mention a statement of preference over other equipment or materials. 
ment Station in Juana Díaz, previously sampled (Estevez de Jensen et al., 2009). Amplification of the 16S rDNA region was carried out in a T3000 thermocycler (Biometra, Goettingen, Germany) using the following conditions: $94^{\circ} \mathrm{C}$ for 2 min initial denaturation, followed by 35 cycles of $94^{\circ} \mathrm{C}$ for $30 \mathrm{~s}, 62^{\circ} \mathrm{C}$ for $30 \mathrm{~s}$ and a final extension for $1 \mathrm{~min}$ at $72^{\circ} \mathrm{C}(\mathrm{Li}$ et al., 2007). Amplification products were visualized by using a UV transluminator after electrophoresis in a $1.0 \%$ agarose gel stained with ethidium bromide. The PCR products of the 16S rDNA region were purified with a QIAquick PCR Purification Kit (Quiagen, Valencia, CA) and sequenced at Macrogen Inc. ${ }^{6}$ (Rockville, MD). DNA sequences were aligned and edited by using BioEdit, Sequence Alignment Editor (versión 7.0.4.1). Sequences were compared with known sequences in the GenBank. Sequence data was deposited in GenBank (Table 2).

Enzyme-Linked ImmunoSorbent Assay (ELISA). Citrus Tristeza Virus was detected using an AGDIA ELISA reagent set (Agdia, Indiana, USA. SRA 78900/0096). The ELISA plate was coated with the capture antibody solution overnight at $4^{\circ} \mathrm{C}$. In an AGDIA sample mesh bag (ACC 00930) $0.1 \mathrm{~g}$ of sample tissue with $1 \mathrm{ml}$ of General Extraction Buffer (GEB) was macerated with an AGDIA tissue homogenizer (ACC 00900) and $100 \mathrm{ml}$ placed in each well. A positive (LPC 78900) and negative control (GEB) were included. After two hours incubation in a humid box at room temperature, the plate was washed three times with Phosphate Buffered Saline plus Tween 20 (PBST) washing buffer. The enzyme conjugate was then placed into the wells and incubated for two hours and after the plate was washed with PBST buffer for seven times. The substrate PNP was prepared and $100 \mathrm{ml}$ was dispensed in the wells and incubated at dark for $60 \mathrm{~min}$. The results were evaluated in an ELISA plate reader (Model ELX808, 24 V, 48 Watts, Biotek). For detection of Citrus Variegated Chlorosis (CVC) an AGDIA ELISA complete AGDIA kit was used (Agdia, Indiana, USA, 34501/0288). Leaf tissue was macerated with GBE buffer and 100 ul dispensed into the wells, positive (LPC 3451) and negative (GEB) controls were included. After two hours incubation in a humid box at room temperature, the plate was washed three times with PBST washing buffer. The Enzyme Conjugate was placed into the wells and incubated for two hours and then was washed with PBST buffer seven times. The substrate PNP was prepared and $100 \mathrm{ml}$ dispensed in the

\footnotetext{
${ }^{6}$ Sequencing service was mentioned to provide specific information and does not constitute a warranty by the University of Puerto Rico, nor is this mention a statement of preference over other sequencing services.
} 
TABLE 2.-Homology found between the sequences of 16S rDNA amplified by PCR and the sequences reported in the GenBank.

\begin{tabular}{|c|c|c|c|c|c|}
\hline \multirow[b]{2}{*}{$\begin{array}{l}\text { GenBank assigned numbers for } \\
\text { Puerto Rican strains }\end{array}$} & \multicolumn{5}{|c|}{ GenBank homology } \\
\hline & Accesion number & Description & $\begin{array}{l}\text { Query } \\
\text { coverage }\end{array}$ & E-Value $^{1}$ & $\begin{array}{l}\text { Max. } \\
\text { Identity }\end{array}$ \\
\hline JX291536 (CG209:Coamo) & $\mathrm{AB} 555706.1$ & Ca. L. asiaticus gene for $16 \mathrm{~S}$ ribosomal RNA & $97 \%$ & 0.0 & $99 \%$ \\
\hline JX291537 (CG241: Santa Isabel) & JN049636.1 & $\begin{array}{l}\text { Ca. L. asiaticus isolate gj2 } 16 \mathrm{~S} \text { ribosomal RNA gene, } \\
\text { partial sequence }\end{array}$ & $99 \%$ & 0.0 & $98 \%$ \\
\hline JX291538 (CG248: Santa Isabel) & DQ471900.1 & Ca. L. asiaticus from USA 16 S ribosomal RNA gene & $100 \%$ & 0.0 & $99 \%$ \\
\hline
\end{tabular}

${ }^{1}$ Chance of favorable homology. A zero value is expected for high percentages of homology among DNA sequences. 
wells and incubated at dark for $60 \mathrm{~min}$. The results were evaluated in an ELISA plate reader (Model ELX808, 24 V, 48 Watts, Biotek).

\section{RESULTS AND DISCUSSION}

A total of 345 citrus samples were collected from 20 farms ( 1 to 235 ha in size) in the central mountains, southern coast, northern and northwest areas of the island (Figure 1). The citrus samples belonged to eight different species, where C. sinensis (42\%), C. reticulata (27\%) and C. latifolia $(12 \%)$ were the most common, whereas C. paradisi $(2 \%)$ and $C$. limon $(1 \%)$ were species less found in the citrus growing areas surveyed.

Common symptoms observed at 20 sampled orchards varied (Figure 2). Leaf symptoms included asymmetric blotch and mottling (Figure 2A); enlarged, swollen and corky veins (Figure 2B); and deformation (Figure 2C). In addition, micronutrient deficiencies, especially zinc and manganese, were noticed at several locations (Figure 2D). Fruit dropping and yellow shoots were also observed.

Candidatus Liberibacter asiaticus was detected by PCR assay in 23 of the 345 samples analyzed from the municipalities of Adjuntas, Añasco, Cabo Rojo, Coamo, Dorado, Juana Díaz, Las Marías and Santa Isabel (Figures 3 to 5) amplified the 16S rDNA fragments of $1,160 \mathrm{bp}$ in an agarose gel at $1.0 \%$ and corresponded to the bacterium $\mathrm{Ca} \mathrm{L}$. asiaticus (Gottwald et al., 1989; Jagoueix et al., 1996; Li et al., 2007). Sequencing of the PCR products from Coamo and Santa Isabel confirmed the identity of $\mathrm{Ca} \mathrm{L}$. asiaticus, with GenBank homology and query coverage over $97 \%$ compared to sequences of the CG bacterium in the database (Table 2).

Citrus Greening was detected in nine samples of $C$. sinensis, seven samples of $C$. reticulata, three samples of C. latifolia and C. aurantifolia, and one sample of $C$. nobilis. However, $C a \mathrm{~L}$. asiaticus was not identified in samples of C. paradisi, C. limon and C. reticulata $\mathrm{x} C$. paradisi collected in the municipalities of Cabo Rojo, Lares, Morovis and Corozal. This finding is similar to what happens in South Africa, where $\mathrm{CG}$ is commonly found in oranges $(C$. sinensis) and mandarin $(C$. reticulata) and in lesser proportion affects lemons (C. limon) (Garcia, 2006). Although all species and cultivars of citrus are susceptible to CG, C. paradisi, C. limon and C. reticulata $\mathrm{x}$ C. paradisi are moderately affected (FAO, 2003).

During the survey three of the 23 positive samples for $\mathrm{Ca}$. L. asiaticus were asymptomatic. Two of these samples were collected from C. sinensis in Añasco and one sample corresponded to a C. reticulata tree in Dorado. The identification of the bacterium from asymptom- 


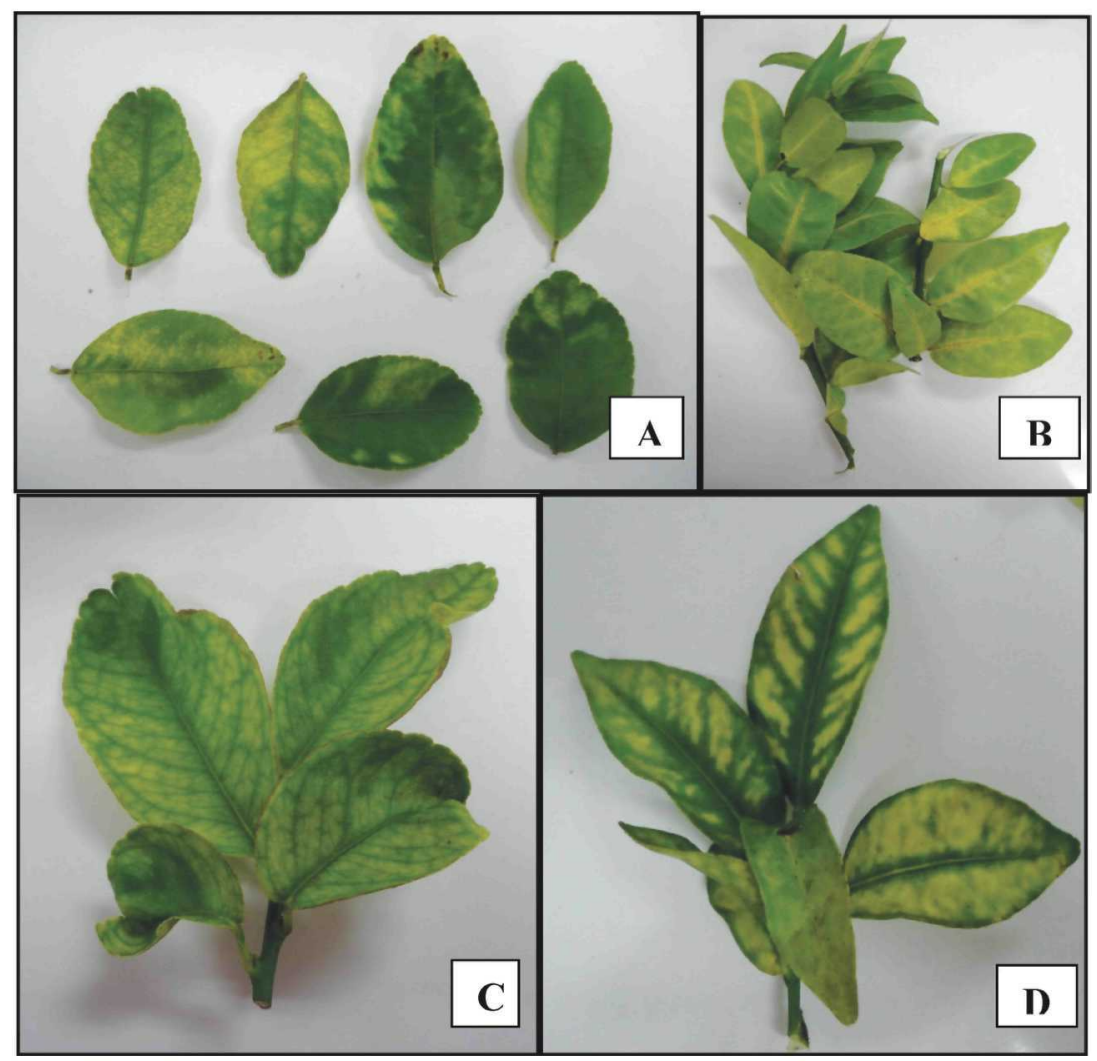

Figure 2. Symptoms observed in Citrus spp. sampled during the survey. (A) Asymmetrical blotchy mottle leaves in C. sinensis samples from Santa Isabel; (B) Midribs and lateral veins enlarged in C. sinensis samples from Sabana Grande; (C) C. latifolia deformed leaves from Juana Díaz; (D) C. reticulata leaves from Lares showing zinc deficiency symptoms.

atic tissue corroborates the non-specific nature of the symptoms of CG (Bové, 2006; Folimonova and Achor, 2010) and that the PCR assay performed during this study was sensitive enough to detect the pathogen in early stages of the disease development. The number of adults of $D$. citri in young shoots collected from the middle section of the trees at orchards located in Adjuntas, Añasco, Coamo, Juana Díaz and Dorado were registered. The population of $D$. citri adults was higher in orchards located on the coastal municipalities of Añasco (20), Dorado (12) and Juana Díaz (10). Fewer psyllids were observed in samples from the mountainous region of Adjuntas (1) and Coamo (4). 


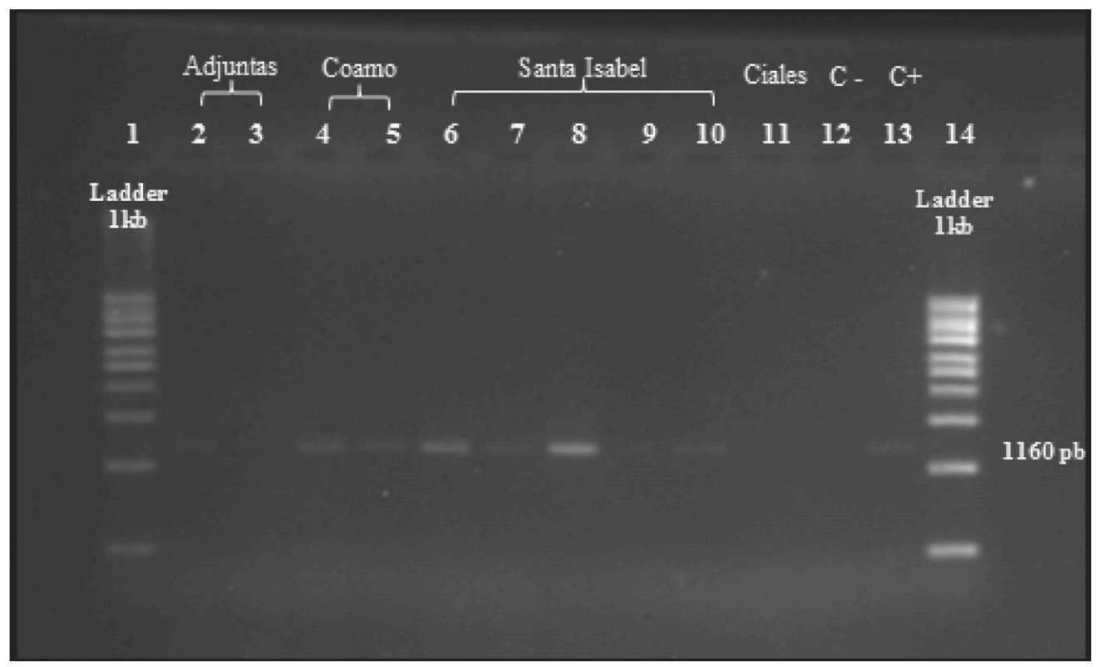

FIGURE 3. Agarose gel electrophoresis showing $C a$. L. asiaticus PCR products $(1,160$ bp) using the $\mathrm{O} 1$ and $\mathrm{OI} 2$ species specific primers. 1 and 14: Ladder 1Kb; 2: CG158 (Adjuntas); 3: CG159 (Adjuntas); 4: CG208 (Coamo); 5: CG209 (Coamo); Samples 6: CG241, 7: CG246, 8: CG248, 9: CG249, and 10: CG250 from Santa Isabel; 11: CG251 (Ciales); 12: Negative control; 13: Positive control CG151.

Coastal valleys of Añasco, Dorado and Juana Díaz have an average temperature of $28^{\circ} \mathrm{C}$. Collection of samples in these orchards was conducted in the months of March and December, considered dry season because of low precipitation levels (approximately $23 \mathrm{~mm}$ ) (USGS, 2012). According to Aubert (1987), the weather in coastal areas where high temperatures and low humidity prevail favored the development of $D$. citri populations. Similarly, Sohail et al. (2004) showed that a negative correlation existed between relative humidity and population numbers of $D$. citri.

Samples from Adjuntas and Coamo were collected during the month of April (2011), when temperatures ranged between 16 and 27 ${ }^{\circ} \mathrm{C}$ and precipitation was $144 \mathrm{~mm}$ in the Experiment Station at Adjuntas (NOAA, 2012). The number of $D$. citri adults observed in this region may be associated with high level of precipitation. The density of psyllid nymphs and eggs decreased because of a knock down effect by washing; the $D$. citri eggs were on top of the plant shoots, which makes the nymphs completely exposed to the impact of rain (Aubert, 1987).

The impact on $D$. citri population by previously identified parasitoids in Puerto Rico is unknown. In a survey of potential natural enemies of $D$. citri in citrus production areas in Puerto Rico, Pluke et al. (2005) found Tamarixia radiata Waterston and eight species of 


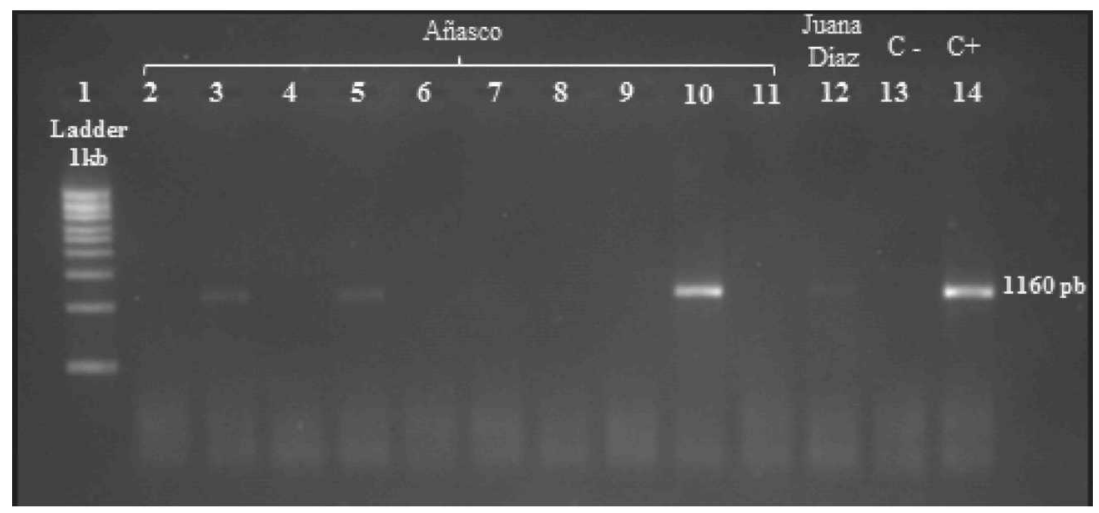

FIGURE 4. Agarose gel electrophoresis showing $\mathrm{Ca}$. L. asiaticus PCR products (1,160 bp) using the $\mathrm{O} 1$ and OI2 species specific primers. 1: Ladder 1Kb; Samples 2: CG599, 3: CG600, 4: CG601, 5: CG602, 6: CG603, 7: CG604, 8: CG605, 9: CG606, 10: CG607, 11: CG608 from Añasco; 12: CG609 (Juana Díaz); 12: Negative control; 14: Positive control CG151.

coccinellids. Coccinellids typically respond to dense prey populations whereas parasitoids with narrow host ranges such as $T$. radiata are expected to track their host population at low densities (Pluke et al., 2005). It is necessary to conduct studies to determine the population

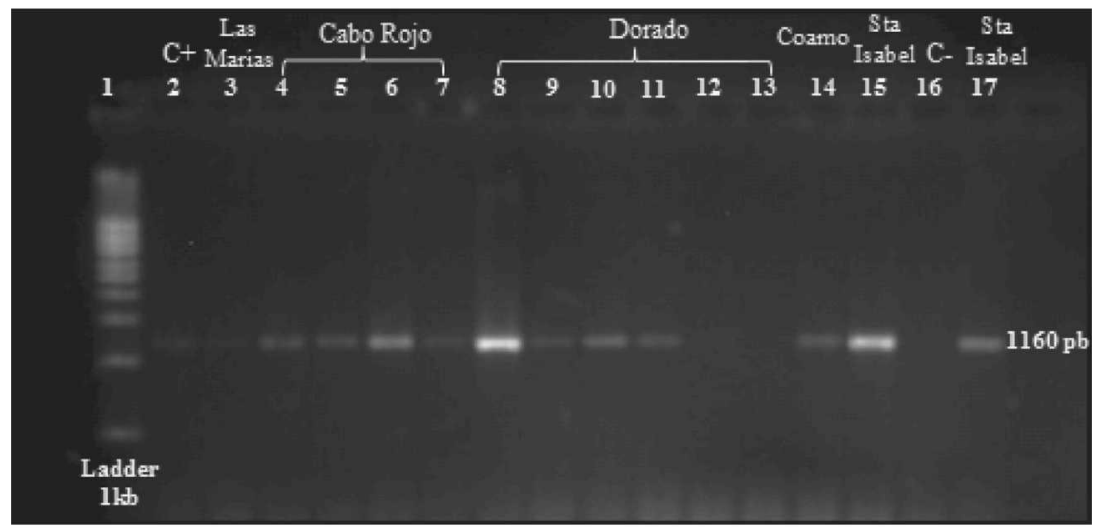

FIGURE 5. Agarose gel electrophoresis showing $C a$. L. asiaticus PCR products $(1,160$ bp) using the $\mathrm{O} 1$ and $\mathrm{OI} 2$ species specific primers. 1 and 14: Ladder 1Kb; 2: Positive control CG151; 3: CG295 (Las Marías); Samples 4: CG314, 5: CG338, 6: CG342, 7: CG346 from Cabo Rojo; Samples 8: CG415, 9: CG417, 10: CG418, 11:CG419, 12: CG433, 13: CG434 from Dorado; 14: CG209 (Coamo); 15: CG241 (Santa Isabel); 16: Negative control; 17: CG248 (Santa Isabel) 
dynamics of $D$. citri and its natural enemies in Puerto Rico, and also to identify the pathogen $C a$. L. asiaticus in $D$. citri.

Despite the widespread presence of symptoms of CG, the number of positive samples of $\mathrm{Ca}$. L. asiaticus was low (7.0\%). The disease was diagnosed also in asymptomatic trees, indicating that PCR was able to detect the pathogen in samples with a low titer of the bacteria. The detection of CTV and CVC in samples that were negative for CG during the survey suggests that similar symptoms observed for CG may also be associated with these diseases (Marroquin-Guzman et al., 2012).

Samples of C. sinensis (CG260) from Ciales with symptoms of zinc deficiency were negative for CG. This same sample tested positive for a xylem limited bacterium, Xyllela fastidiosa, causal agent of CVC, detected by a Double Antibody Sandwich-Enzyme-Linked ImmunoSorbent Assay (DAS- ELISA, Agdia $($ - 34,501) (Marroquin-Guzman et al., 2012).

The presence of CTV was detected by Triple Antibody Sandwich (TAS-ELISA, Agdiaß Kit, SRA78900) in 41 samples of orange, tangerine, lemon, tangelo and lime collected in the municipalities of Adjuntas, Arecibo, Cabo Rojo, Ciales, Dorado, Isabela and Villalba (MarroquinGuzman et al., 2012). Symptoms observed on trees were small leaves, yellowing and midribs enlarged and swollen (Figure 2B).

Detection of CG in commercial nursery plants (Las Marías, Cabo Rojo and Isabela) and orchards in eight municipalities of Puerto Rico (Figure 1) indicates the potential for the dissemination of the disease to new orchards. The beginning of a successful citrus production in Puerto Rico depends on planting disease-free trees, controlling the presence of vectors and monitoring diseases like CG, CTV and CVC, all of them transmitted through propagation material in nurseries and orchards around the island.

\section{LITERATURE CITED}

Anonymous, 2011. Informe Anual de la Empresa de Frutales. Universidad de Puerto Rico, Departamento de Cultivos y Ciencias Agroambientales. Mayagüez, Puerto Rico. p. 15.

Aubert, B., 1987. Trioza erytreae del Guercio and Diaphorina citri Kuwayama (Homoptera: Psyllodea), the two vectors of citrus greening disease. Pp. 226-230. In: Timmer, L. W., S. M. Garnsey and L. Navarro (eds.), Proc. 10th Conference of the International Organization of Citrus Virologists. Riverside, CA.

Bové, J. M., 2006. Huanglongbing: A destructive, newly-emerging, century-old disease of Citrus. Joumal of Plant Pathology 88 (1): 7-37.

Brlansky, R. H. and M. E. Rogers, 2007. Citrus huanglongbing: Understanding the vector-pathogen interaction for disease management. Plant Health Progress. Published online: http://www.apsnet.org/publications/apsnetfeatures/Pages/Huanglongbing.aspx. 
Callaway, E., 2008. Bioterror: The green menace. Nature 452(7184): 148-150.

Estevez de Jensen, C., F. Román, E. Abreu, A. Alvarado and O. Ortiz, 2009. Presencia del "Enverdecimiento de los Cítricos" en Puerto Rico. Resúmenes Sociedad Puertorriqueña de Ciencias Agrícolas. Pp. 7.

Estévez de Jensen, C., A. Vitoreli and F. Román, 2010. Citrus greening in commercial orchards in Puerto Rico. Phytopathology 100: S34.

FAO (Food and Agriculture Organization of the United Nations), 2003. Examen de los problemas fitosanitarios actuales relacionados con los cítricos y de las políticas aplicadas para afrontarlos. Comité de problemas de productos básicos, grupo intergubernamental sobre frutos cítricos. $13^{a}$ reunión. La Habana, Cuba. 20-23 de mayo de 2003. 14 P. En línea (Consultado Julio 2012): ftp:/ftp.fao.org/docrep/fao/meeting/006/y 9061 s.pdf.

Folimonova, S. Y. and D. S. Achor, 2010. Early events of citrus greening (Huanglongbing) disease development at the ultrastructural level. Phytopathology 100:949-958.

García, C., 2006. Huanglongbing (HLB Greening). Dirección de Vigilancia y Monitoreo. En línea (Consultado Julio de 2012): http:// www.senasa.gov.arg.

Gottwald, T. R., B. Aubert and X. Y. Zhao, 1989. Preliminary analysis of citrus greening (Huanglongbing) epidemics in the People's Republic of China and French Reunion Island. Phytopathology 79: 687-693.

Gottwald, T. R., J. V. Da Graca and R. B. Bassanezi, 2007. Citrus Huanglongbing: The pathogen and its impact. Plant Health Progr. Published on line.

Gottwald, T. R., 2010. Current epidemiological understanding of Citrus Huanglongbing. Annual Review of Phytopathology 48:119-39.

Halbert, S. E. and C. A. Núñez, 2004. Distribution of the Asian Citrus psyllid Diaphorina citri Kuwayama (Rhynchota: Psyllidae) in the Caribbean Basin. Florida Entomologist 87(3): 401-402.

Jagoueix, S., J. M. Bové and M. Garnier, 1994. The phloem-limited bacterium of greening disease of citrus is a member of the alpha-subdivision of the Proteobacteria. International Journal of Systematic and Evolutionary Microbiology 44(3): 379-386.

Jagoueix, S., J. M. Bové and M. Garnier, 1996. PCR detection of the two 'Candidatus' Liberibacter species associated with greening disease of citrus. Molecular and Cellular Probes 10: 43-50.

Li, W., J. S. Hartung and L. Levy, 2007. Evaluation of DNA amplification methods for improved detection of "Candidatus Liberibacter Species" associated with Citrus Huanglongbing. Plant Disease 91: 51-58.

Marroquín-Guzmán, M. R., C. Estévez de Jensen and E. Martínez, 2012. Prevalent citrus diseases in Puerto Rico. Phytopathology 102: S6.4.

NOAA, 2012. National Oceanic and Atmospheric Administration National Weather Service. Online (Consulted September 2010): http://www.nws.noaa.gov/climate/.

Pluke, R. W. H., A. Escribano, J. P. Michaud and P. A. Stansly, 2005. Potential impact of lady beetles on Diaphorina citri (Homoptera: Psyllidae) in Puerto Rico. Florida Entomologist 88 (2): 123-128.

Sohail, A., A. Nisar and R. Rasool, 2004. Studies on population Dynamics and Chemical Control of Citrus Psylla, Diaphorina citri. International Journal of Agriculture and Biology 6: 970-973.

Stokstad, E., 2006. Agriculture. New disease endangers Florida's already suffering citrus trees. Science 312(5773): 523-524.

Sutton, B., Y. P. Duan, S. Halbert, X. Sun, T. Schubert and W. Dixon, 2005. Detection and identification of citrus Huanglongbing (greening) in Florida, USA. Pp. 59 in: Proceedings of the Second International Citrus Canker and Huanglongbing Research Workshop, Orlando, FL, U.S.A. 
Teixeira, D., 2005. First report of a Huanglongbing-like disease of citrus in São Paulo State, Brazil, and association of a new liberibacter species, 'Candidatus Liberibacter americanus', with the disease. Plant Disease 89:107.

USDA, 2011. Salve los cítricos. On line (July 2011): http://salveloscitricos.org/ practicesafe-citrus/.

USGS, 2012. Water Resources of the Caribbean. On line (September, 2012): http:/ pr.water.usgs.gov/.

Yokomi, R. K., D. Rivera, S. M. Garnsey, T. R. Gottwald, E. Abreu-Rodriguez, V. Damsteegt, P. A. Stansly, V. J. Febres and C. L. Niblett, 1996. Incidence of Brown Citrus Aphid and Citrus Tristeza Virus in Puerto Rico. Thirteenth IOCV Conference, 1996Citrus Tristeza Virus.

Zapata, M., J. Hartung, B. Brodbeck and P. Andersen, 2011. Endophytic bacteria from the vascular tissue of coffee (Coffea arabica L.) and citrus (Citrus sinensis L.) leaves found during the attempt to isolate the pathogen, Xylella fastidiosa in Puerto Rico. Phytopathology 101:\$279. 